\title{
KEBERHASILAN SISTEM INFORMASI AKUNTANSI DIDETERMINASI OLEH ETIKA PENGGUNA
}

\author{
Sri Dewi Anggadini \\ Program Studi Akuntansi BUMN \\ sri.dewi@email.BUMN.ac.id
}

\begin{abstract}
ABSTRAK
Etika pengguna merupakan prinsip moral bagi seseorang yang berkaitan dengan perilaku baik dan buruk dalam menjalankan aktivitas SIA.Keberhasilan SIA adalah integrasi semua unsur disebut juga komponen SIA.Tujuannya yaitu untuk mengetahui besarnya sistem informasi akuntansi yang dideterminasi oleh etika pengguna.Berdasarkan hasil penelitian ini dapat diajdikan masukan pada Badan Usaha Milik Negara untuk menerapkan budaya etis, tanggung jawab, disiplin kerja, loyal dan patuh serta memberikan yang terbaik bagi organisasi. Metode penelitian yang digunakan bersifat deskriptif verifikatif dan termasuk survey research..Teknik pengumpulan data menggunakan kuesioner dan wawancara.Unit analisis dalam penelitian ini adalah bagian Akuntansi Keuangan di BUMN.Untuk analisis data menggunakan pemodelan strukural SEM-PLS (Structural Equation Model- Partial Least Square).Hasil penelitian menunjukkan bahwa etika pengguna berpengaruh terhadap kualitas sistem informasi akuntansi. Namun, berkualitasnya SIAdisebabkan responsibility, accountability dan liability belum sepenuhnya diakomodir di dalam penggunaan. Responsibility artinya bahwa karyawan BUMN secara rata-rata memiliki rasa tanggung jawab terhadap pekerjaan yang ditugaskannya. Accountability artinya karyawan BUMN dalam penggunaan sistem informasi akuntansi seringkalimenerima tanggung jawab.Liability artinya karyawan BUMN dalam penggunaan sistem akuntansi perusahaan seringkaliberupaya untuk mencari solusi yang terbaik. Berdasarkan pengolahan data bahwa penerapanSIA belum sepenuhnya mengadopsi etika yang dimiliki pengguna dalam menggunakan sistem informasi akuntansi.
\end{abstract}

\section{Kata Kunci : Etika Pengguna dan Keberhasilan Sistem Informasi Akuntansi.}

\section{PENDAHULUAN}

Sistem informasi akuntansi penting bagi kehidupan organisasi (Jawadekar, 2009:8) dan bagi perkembangan akuntansi.Terintegrasinya suatu sistem informasi menurut Marcus (2009) sebagai proses menghasilkan informasi yang terorganisir di dalam sistem informasi yang terdiri dari hardware, software, databases dan telecommunication network, serta adanya interaksi dan komunikasi manusia sebagai
pengguna.Selanjutnya O’Brien \& Marakas (2011:65) menyatakan sistem informasi diimplementasikan dengan baik tergantung dari keharmonisan atas orang, hardware, software, data dan networks yang merupakan sumber daya utama dari sebuah sistem informasi.

Heidmann (2008:87) mengungkapkan bahwa ukuran dari kualitas sistem informasi adalah integration, flexibility, accessibility, formalization dan media richness.DeLone \& 
McLean (2003) menyatakan bahwa kesuksesan dari model sistem informasi diukur dengan system quality, information quality, service quality, intention to use, user satisfaction dan net benefits. O'Brien \&Marakas (2011:51) menyatakan keberhasilan sistem informasi tidak hanya diukur dari sisi efisiensi, dalam hal ini biaya minimal, waktu sumber daya informasi yang digunakan, tetapi keberhasilan tersebut diukur juga melalui efektivitas dari teknologi informasi yang mendukung strategi bisnis organisasi.

Rendahnya kualitas sistem informasi akuntansi terjadi pada organisasi Badan Usaha Milik Negara (BUMN).Mustafa Abubakar (2010) menyatakan terjadi kesalahan dalam penerapan sistem informasi PT Garuda Indonesia.Sependapat dengan Budi Firman (2013) mengungkapkan banyaknya sistem informasi di lingkungan kerja PTPN VII yang belum terintegrasi sepenuhnya. Selanjutnya, M. Kuncoro W (2014) mengakui bahwa implementasi sistem informasi PT KAI seringkali gagal, dari sisi waktu implementasi yang lama, biaya yang membengkak hingga tidak sesuai dengan kebutuhan bisnis.

Menurut Uchok Sky Khadafi (2012) menyatakan salah satu faktor penyebab potensi penyimpangan di BUMN adalah kelemahan sistem pengendalian pelaksanaan anggaran perusahaan dan kelemahan struktur pengendalian intern serta tidak ada pemisahan tugas dan fungsi yang memadai pada BUMN termasuk SOP yang jarang ditaati. Dalam menjalankan tugasnya melalui pengembangan sistem, para pengguna harus memastikan bahwa konsep etikanya menyebar di seluruh organisasi, melalui semua tingkatan dan menyentuh semua karyawan (Mc. Leod \& Schell, 2007:234).

Dalam menjalankan tugasnya dalam pengembangan sistem, pengguna sistem.informasi memastikan bahwa konsep etikanya menyebar di seluruh organisasi, melalui semua tingkatan dan menyentuh semua karyawan (McLeod \& Schell, 2007:234).Oleh karena itu, peningkatan perilaku etis harus dimulai dari manajemen puncak (Griffin, 2011:108).Etika menurut Laudon \& Laudon (2014:155) merupakan prinsip-prinsip mengenai kebenaran dan kekeliruan yang dapat digunakan individu, bertindak sebagai agen-agen moral bebas, dalam membuat pilihan-pilihan untuk menuntun perilakunya.Ketika sistem informasi diimplementasikan, etika menjadi sangat penting sebagai pedoman bagi pihak manajemen dalam rangka pengembangan teknologi yang sedang diterapkan (Piccoli, 2008:450).Etika sangat diperlukan dalam menjalankan aktivitas organisasi untuk mencapai hasil berupa kinerja yang professional (Alter, 2002:286) merupakan faktor yang berdampak pada keberlangsungan sistem informasi (Ballantine et al., 2000).

\section{RERANGKA TEORITIS}

\section{Etika Pengguna}

Etika menurut Laudon \& Laudon (2014:159)adalah perilaku manusia yang memiliki kebebasan memilih.Etika adalah tentang pilihan invidual.Pendapat yang sama disampaikan oleh Dessler (2013:461) menyatakan etika mengacu pada prinsip-prinsip perilaku yang mengatur individu atau kelompok yang menggunakan standar perilaku yang harus dilakukan (ethics refers to the principles of 
conduct governing an individual or a group ; specifically, the (return), Penerapan etika sangat penting bagi seluruh profesi (Schwalbe, $\underline{\text { 2006:30). }}$.

Bagranoff et al (2010:333) bahwa etika adalah seperangkat digunakan dalam membuat pilihan dan membimbing perilaku mereka dalam situasi yang melibatkan konsep benar dan salah.

Selanjutnya McLeod \& Schell (2007:262) menyatakan bahwa etika adalah satu set kepercayaan, standar atau pemikiran yang mengisi suatu individu, kelompok atau masyarakat. Semua individu bertanggung jawab kepada masyarakat atas perilaku mereka.

Etika harus dimiliki para pengguna dalam mengoperasikan sistem informasi (Laudon \& Laudon, 2014:160).McLeod \& Schell (2007:108) menjelaskan definisi pengguna adalah pengguna akhir identik dengan pengguna; pengguna merupakan seseorang yang menggunakan produk akhir dari suatu sistem berbasis komputer.

Pengguna sistem informasi dalam sebuah organisasi sangat penting keberadaannya dalam menghasilkan informasi yang akan berkontribusi secara nyata dalam menjalankan strategis dan mencapai keunggulan bersaing (McLeod \& Schell. 2007:109). Bodnar \&Hopwood (2014:158) menambahkan pengguna terdiri dari kelompok orang heterogen dan dapat dibedakan dari yang lain karena berdasarkan fungsinya yang berkaitan dengan pengolahan data atau teknologi informasi. Azhar Susanto (2013:14) menyampaikan bahwa pengguna sistem informasi terdiri dari internal dan eksternal.

Robbins \& Judge (2014:92) menyatakan terdapat 3 (tiga) kriteria etika antara lainutilitarianism, whistle-blowers dan creativity. 60
McShane \& Glinow (2010:53) berpendapat terdapat 3 (tiga) prinsip dasar etika yaitu:

\section{1) Utilitarianism}

Prinsip moral yang menyatakan bahwa dalam mengambil keputusan dari berbagai alternatif harus yang paling bermanfaat bagi orang banyak.

\section{2) Individual right}

Prinsip moral yang menyatakan bahwa setiap orang berhak atas hukum dan haknya masingmasing.

\section{3) Distributive justice}

Prinsip moral yang menyatakan bahwa semua orang harus dihargai sesuai dengan porsinya masing-masing.

O’Brien \& Marakas (2011:532) dan Gupta (2011:380) mengungkapkan dimensi moral berkaitan secara khusus dengan pengunaan bentuk sistem informasi apapun dan secara garis besar memiliki 4 (empat) prinsip antara lain : Proportionality (proporsional), Informed Consent (persetujuan berdasarkan informasi), Justice (keadilan) dan Minimized Risk (minimalisasi risiko). Laudon \& Laudon (2014:159-160) mengungkapkan konsep dasar dari etika pengguna dalam penerapan sistem informasi antara lain :

1) Tanggung jawab (responsibility)

Tanggung jawab adalah unsur kunci dari tindakan etis yang berarti menerima dari segala bentuk biaya, tugas dan keharusan dari keputusan yang dibuat.

2) Akuntabilitas (accountability)

Akuntabilitas dari sistem dan institusi sosial, artinya mekanisme ada pada, tempatnya dalam menentukan siapa yang bertanggung jawab, siapa yang bertindak. 
3) Kewajiban (liability)

Adalah fitur sistem politik dimana badan hukum berada pada tempatnya yang mengizinkan individu untuk dipulihkan dari kerusakan atau kerugian yang diperbuat oleh pelaku lain, sistem atau organisasi.

Indikator dari setiap dimensi etika pengguna tersebut adalah:

1) Tanggung jawab (responsibility)

a) Tanggung jawab atas tindakan yang dilakukan.

b) Menjalankan aktivitas yang direncanakan.

(Hartman \& Desjardins, 2008:7)

2) Akuntabilitas (accountability)

a) Menerima tanggung jawab yang ditugaskan.

b) Memberikan contoh bagi orang lain. (Dellaportaset al., 2005:101).

3) Kewajiban (liability)

a) Kewajiban untuk loyal dan patuh

b) Kewajiban dalam menjaga kerahasiaan (Dellaportaset al., 2005:101).

\section{Kualitas Sistem Informasi Akuntansi}

Peran mendasar sistem informasi akuntansi dalam organisasi adalah menghasilkan informasi akuntansi yang berkualitas( $\underline{\text { Susanto, 2013:374).Menurut Weber (1999:895) }}$

kualitas sistem adalah serangkaian karakteristik yang dapat terlihat oleh pengguna setelah mereka berinteraksi dengan sistem tersebut pada waktu tertentu. DeLone \& McLean (1992\&2003) menggunakan istilah kesuksesan untuk menunjukkan kualitas sistem informasi, sedangkan Stair \& Reynolds (2010: 57) menunjukkan kualitas dengan istilah kepuasan pemakai.Kualitas sistem informasi akuntansi diartikan sebagai bentuk pernyataan tentang kondisi dimana sistem informasi akuntansi dapat menghasilkan informasi akuntansi yang sesuai dengan kebutuhan user. Informasi akuntansi yang berkualitas diperoleh dari hasil penerapan sistem informasi akuntansi yang berkualitas (Sacer et al., 2006).

Senada dengan yang disampaikan Wixom \&Todd (2005) bahwa karakteristik sistem informasi yang berkualitas adalah kehandalan, fleksibilitas, integrasi, accesibility dan tepat waktu.Selanjutnya Horan\& Abhichandani (2006)menyatakan bahwa karakteristik kualitas dari sistem informasi adalah utilities, reliabel, efisiensi, kustomisasi dan fleksibilitas.Begitu pula Baltzan (2014:184) mengungkapkan bahwa karakteristik kualitas sistem informasi jika sistem informasi tersebut memiliki kemampuan dalam hal accessibility, availability, maintainability, portability, reliability, scalability dan usability. Pendapat senada juga disampaikan oleh Gorla et al. (2010) bahwa kualitas sistem informasi diukur dari technically sound, error-free, easy to learn, user friendly, well documented dan flexible.

Sedangkan O'Brien \& Marakas (2011:17) mengukur keberhasilan sistem informasi tidak seharusnya diukur hanya melalui efisiensi dalam hal meminimalkan biaya, waktu dan penggunaan sumber daya informasi. Keberhasilan juga diukur dari efektivitas teknologi informasi dalam mendukung strategi bisnis, memungkinkan proses bisnisnya, meningkatkan struktur organisasi dan budaya, serta meningkatkan nilai pelanggan dan bisnis perusahaan.

Azhar Susanto (2013:72) bahwa kualitas sistem informasi akuntansi adalah integrasi semua unsur atau komponen yang terdiri dari 
hardware, software, brainware, prosedur, database dan jaringan komunikasi. Semua komponen memiliki hubungan satu sama lain dan didalam setiap komponen tersebut terdiri dari beberapa komponen yang juga saling berhubungan.

Dunn et al. (2005:2) mengungkapkan bahwa integrasi merupakan salah satu dimensi dari sistem yang berkualitas. Sistem informasi akuntansi yang terintegrasi merupakan satu set jaringan komunikasi dalam organisasi bisnis, dikombinasikan secara bersama-sama untuk membentuk suatu kesatuan yang menampung dan menyebarkan informasi.

Heidmann (2008:88) menjelaskan sistem dapat dikatakan fleksibel apabila sistem tersebut dapat beradaptasi dengan berbagai macam kebutuhan pengguna dan dapat beradaptasi dengan berbagai macam perubahan kondisi yang terjadi dalam organisasi flexibility measures the degree to which a system can adapt to a variety of user needs and to changing condition). Sistem tersebut dapat menyesuaikan dengan perubahan tuntutan dari pengguna (Wixom \& Todd, 2005).

Berdasarkan beberapa penjelasan tersebut, maka kualitas sistem informasi akuntansi merupakan kemampuan sistem informasi dalam menyediakan informasi akuntansi yang berkualitas yaitu sesuai dengan kebutuhan user dan berguna dalam pengambilan keputusan, dengan menggunakan karakteristik integration, flexibilitydan reliability(Stair \& Reynold, 2010:57 ;Wixom \& Todd, 2005 ; Horan\& Abhichandani, 2006 ;Baltzan, 2014:184 ;Gorla et al., 2010; Heidmann, 2008:87-90).
Adapun indikator dari setiap dimensi kualitas sistem informasi akuntansi tersebut adalah:

1) Integration

a) Integrasi antara komponen ( $\underline{\text { Sacer, }}$ 2006)

b) Integrasi antara sistem pengolahan transaksi (Azhar Susanto, 2013:72)

2) Flexibilty

a) Mampu menyesuaikan kebutuhan pengguna (Wixom \& Todd, 2005)

b) Mampu beradaptasi dengan perubahan lingkungan (

3) Reliability

a) Dapat diandalkan oleh pengguna (Stair\& Reynold, 2012:7)

b) Bebas dari kesalahan (Thompson \& Baril, 2003:36)

\section{Pengaruh Etika Pengguna Terhadap Kualitas}

\section{Sistem Informasi Akuntansi}

Piccoli (2008:450) menyatakan etika terkait dengan sistem informasi, artinya ketika sistem informasi diterapkan, etika menjadi penuntun bagi perilaku pengguna sesuai dengan aturan yang diterapkan.Laudon \& Laudon (2014:152) mengemukakan bahwa seseorang harus memahami bagaimana beretika yang benar yang diperlukan dalam penggunaan sistem informasi.

Hal tersebut didukung oleh pernyataan menurut Rocheleau (2006:264) yang mengungkapkan bahwa etika berkaitan dengan sistem informasi.Lebih lanjut O'Brien \& Marakas (2011:20) menegaskan bahwa sebagai manajer, pengusaha profesional dan karyawan harus memiliki tanggung jawab etis dalam 
penggunaan sistem informasi. Pendapat lain mengenai keterkaitan etika dengan sistem informasi disampaikan oleh Hall (2011:112) bahwa etika sangat terkait dengan bisnis, sistem informasi dan teknologi komputer. Hasil studi Myers \& Venable (2014) menyimpulkan bahwa terdapat 6 (enam) prinsip etika yang harus diterapkan dalam penggunaan sistem informasi antara lainthe public interest, informedconsent, privacy, honesty and accuracy, property dan quality of the artifact.

Selanjutnya Olumoye (2013) dalam penelitiannya mengungkapkan bahwa etika dalam hal ini tanggung jawab dan akuntabilitas seseorang sangat diperlukan dalam menjalankan aktivitasnya dalam rangka pengembangan sistem informasi.Hal tersebut sependapat dengan $\underline{\text { Chen }}$ et al. (2011)dalam penelitiannya bahwa tanggung jawab pengguna memiliki peran penting dalam meningkatkan kinerja sistem informasi.Isu-isu etis adalah unsur penting dan tidak dapat dihindari dari sistem informasi.Berdasarkan uraian diatas bahwa kualitas sistem informasi akuntansi ditunjukkan dengan penggunaansistem informasi akuntansi dan implementasi sistem informasi dalam sebuah organisasi memperhatikan etika dari para pengguna, sehinggadapat dikatakan bahwa etika pengguna berpengaruh terhadap kualitas sistem informasi akuntansi.

Hipotesis yang diajukan dalam penelitian ini adalah :

H1 : Etika pengguna berpengaruh terhadap keberhasilan sistem informasi akuntansi

H0 : Etika pengguna tidak berpengaruh terhadap keberhasilan sistem informasi akuntansi

\section{METODE PENELITIAN}

\section{Objek Penelitian}

Objek penelitian merupakan sasaran perhatian penelitian untuk mendapatkan jawaban dari permasalahan.Sehubungan dengan permasalahan dalam penelitian ini maka objek penelitian ini adalah Etika Pengguna dan Kualitas SIA.

\section{Metode Penelitian}

Adapun metode penelitian yang digunakan dalam penelitian ini, akan dijelaskan sebagai berikut:

1) Tujuan Penelitian

Penelitian ini termasuk ke dalam survey research.Penelitian ini dapat memberikan gambaran terhadap fenomena-fenomena serta menjelaskan karakteristik dari variabel.

2) Jenis Penelitian (type of investigation) Jenis penelitian ini bersifat deskriptif dan verifikatif. Penelitian ini juga merupakan penelitian bersifat penjelas (explanatory research) atau kausalitas (causal study). Penelitian ini dapat menjelaskan seberapa besar pengaruh variabel independen terhadap variabel dependen.

3) Perspektif Horizon Waktu

Penelitian ini termasuk ke dalam kelompok studi antar waktu (cross-sectional studies).

\section{Operasionalisasi Variabel}

Dalam penelitian ini, operasionalisasi variabel akan dilakukan dengan tahap sebagai berikut :

1) Mendefinisikan variabel-variabel yang digunakan dalam penelitian. 
2) Menjabarkan variabel menjadi sub-sub variabel.

3) Menjabarkan masing-masing sub variabel ke dalam indikator-indikatornya.

Berdasarkan hasil sintesa kajian pustaka maka penelitian ini menggunakan variabel sebagai berikut :

1) Etika Pengguna

Etika pengguna merupakan prinsip moral bagi seseorang yang berkaitan dengan perilaku baik dan buruk dalam menjalankan aktivitas sistem informasi akuntansi (Laudon \& Laudon, 2014:159; Dessler, 2013:461; Schwalbe, 2006:30). Pengukuran untuk konsep etika pengguna dalam penelitian ini adalah:

1) Tanggung jawab (responsibility)

a) Tanggung jawab atas tindakan yang dilakukan.

b) Menjalankan aktivitas yang direncanakan (Hartman \& Desjardins, 2008:7).

2) Akuntabilitas (accountability)

a) Menerima tanggung jawab yang ditugaskan.

b) Memberikan contoh bagi orang lain(Dellaportas, et al., 2005:101)

3) Kewajiban (liability)

a) Kewajiban untuk loyal dan patuh.

b) Kewajiban dalam menjaga kerahasiaan (Dellaportas, et al., 2005:101).

2) Kualitas Sistem Informasi Akuntansi.

Kualitas sistem informasi akuntansi merupakan kemampuan sistem informasi dalam menyediakan informasi akuntansi yang berkualitas yaitu sesuai dengan kebutuhan user dan berguna dalam pengambilan 64 keputusan, dengan menggunakan karakteristik integration, flexibility dan reliability (Stair \& Reynold, 2010:57; Wixom \& Todd, 2005; Horan \& Abhichandani, 2006; Baltzan, 2014:184; Gorla et al., 2010; Heidmann, 2008:87-90). Pengukuran untuk konsep kualitas sistem informasi akuntansi dalam penelitian ini adalah:

\section{1) Integration}

a) Integrasi antara komponen (Sacer, 2006).

b) Integrasi antara sistem pengolahan transaksi (Azhar Susanto, 2013:72).

\section{2) Flexibilty}

a) Mampu menyesuaikan kebutuhan pengguna (Wixom \& Todd, 2005).

b) Mampu beradaptasi dengan perubahan lingkungan(Heidmann, 2008:88).

\section{3) Reliability}

a) Dapat diandalkan oleh pengguna (Stair \& Reynold, 2012:7).

b) Bebas dari kesalahan (Thompson \& Baril, 2003:36).

\section{Teknik Pengumpulan Data}

Data primer diperoleh dari responden dengan teknik pengumpulan data sebagai berikut

1. Kuesioner, yaitu daftar pernyataan yang ditujukan kepada manajer akuntansi / keuangan, kepala bagian akuntansi/keuangan dan staff akuntansi/keuangan yang ada BUMN.

2. Wawancara yaitu pengajuan pertanyaan dan tanyajawab langsung dengan manajer akuntansi/keuangan, kepala bagian 
akuntansi/keuangan atau staff akuntansi/keuangan yang ada di BUMN.

Adapun pengambilan sampel dilakukan secara acak dengan tidak memperhatikan strata BUMN karena teknik pengambilan sampel pada penelitian ini menggunakan simple random sampling. Sampel yang didapatkan pada penelitian ini berasal dari pengembalian kuesioner dari keseluruhan target populasi sehingga terkumpul sebanyak 58 BUMN.

\section{Analisis Data}

Analisis data dalam penelitian ini dilakukan dengan 2 (dua) jenis analisis agar sesuai dengan tujuan penelitian, yaitu analisis deskriptif dan analisis verifikatif. PLS-SEM digunakan karena model pengukuran yang dibangun melibatkan model pengukuran formatif dan ukuran sampel yang digunakan kecil (30 sampai 80). Di dalam PLS-SEM terdapat dua sub model, yaitu outer model dan inner model.

\section{Evaluasi Model PLS-SEM}

Model pada Structural Equation Modeling (SEM) melalui pendekatan Partial Least Square $(P L S)$ terdiri dari dua jenis yaitu evaluasi model

$l_{i}=\quad \begin{aligned} & \text { melambangkan bobot outer } \\ & \text { terstandarisasi dari variabel } \\ & \text { indikator i dari konstruksi } \\ & \text { tertentu. }\end{aligned}$
$e_{i}=\begin{aligned} & \text { adalah kesalahan pengukuran } \\ & \text { variabel indikator i }\end{aligned}$
$\operatorname{Var}\left(e_{i}\right)=\quad \begin{aligned} & \text { menunjukan varians dari } \\ & \text { kesalahan pengukuran yang } \\ & \text { didefinisikan sebagai } 1-l_{i}{ }^{2}\end{aligned}$

pengukuran (outer model) dan evaluasi model struktural (inner model).

1) Evaluasi Model Pengukuran (Outer Model)

\section{a) Model Pengukuran Reflektif}

Tujuan dari penilaian model pengukuran reflektif adalah untuk memastikan reliabilitas dan validitas. Evaluasi pengukuran reflektif dapat dilakukan sebagai berikut :

\section{1) Validitas Indikator}

Validitas masing-masing indikator reflektif dilihat dari signifikansi loading factor-nya (Bollen, 1989:199).

\section{2) Reliabilitas Indikator}

Ukuran reliabilitas dari suatu indikator reflektif adalah nilai $\mathrm{R}^{2}$ (Bollen, 1989:221). Suatu indikator dikatakan reliabel jika nilai $\mathrm{R}^{2}$-nya tidak kurang dari 0,5 .

\section{3) Validitas Konvergensi}

Batasan indikator-indikator suatu dimensi mempunyai validitas konvergensi yang baik adalah AVE yang bernilai 0,5 ke atas (Hair et al., 2014:103).

\section{4) Reliabilitas Konsistensi Internal}

Uji reliabilitas untuk membuktikan akurasi, konsistensi dan ketepatan

instrumen dalam mengukur konstruk. Untuk reliabilitas digunakan nilai Pc (composite reliability) dengan menggunakan rumus berikut :

$$
\rho_{c}=\frac{\left(\begin{array}{c}
\sum l i \\
i
\end{array}\right)^{2}}{\left(\begin{array}{c}
\sum_{i} l i \\
{ }^{2}
\end{array}\right)^{2}+\sum_{i} \operatorname{var}\left(\theta_{i}\right)},
$$

Keterangan :

\section{5) Validitas Diskriminan}

Evaluasi ini dilihat berdasarkan Kriteria Fornell-Lacker (Hair et al., 2014:104). 
b) Model Pengukuran Formatif

\section{1) Kolinieritas}

Suatu indikator dikatakan berkolinieritas dengan indikator lainnya jika nilai VIFnya lebih besar dari 5 .

2) Signifikansi dan Relevansi Bobot Outer (Outer Weights)

Relevansi pengukuran model formatif dilihat dari signifikansi koefisien komponennya.

\section{2) Evaluasi Model Struktural (Inner Model)}

Menurut Hairet al., (2014:97), evaluasi untuk model struktural adalah:

1) Menguji masalah kolinieritas. Kolinieritas dilihat dari nilai VIF. Suatu indikator dikatakan berkolinieritas dengan indikator lainnya jika nilai VIF-nya lebih besar dari 5.

2) Koefisien determinasi $\left(R^{2}\right)$. $R^{2}$ merupakan sebuah ukuran dari keakuratan prediktif dari sebuah model.

3) Size and significance of path coefficient. Nilai signifikansi dapat dilihat dari nilai- $p$ dan nilai-t. Bila nilai-p lebih kecil dari $\alpha$ maka dianggap signifikan.

\section{HASIL PENELITIAN DAN PEMBAHASAN}

\section{Tingkat Pengembalian Kuesioner}

Sampel yang didapatkan pada penelitian ini berasal dari pengembalian kuesioner dari keseluruhan target populasi sehingga terkumpul sebanyak 58 BUMN. Hal ini disebabkan response rate yang rendah dari target populasi. 66
Ringkasan tingkat pengembalian kuesioner disajikan pada

4.1 berikut :.

Tabel 4.1

Rekapitulasi Tingkat Pengembalian

Kuesioner.

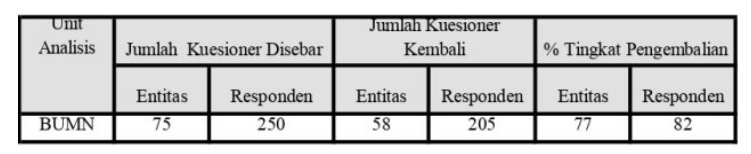

\section{Analisis Deskriptif}

Analisis deskriptif dengan menggunakan perhitungan skor konstruk, dengan langkahlangkah sebagai berikut:

1. Menghitung skor konstruk berdasarkan model regresi dengan koefisien berupa nilai taksiran weight untuk masing-masing indikator dari setiap konstruk.

2. Menghitung nilai minimum dan maksimum dari setiap konstruk dengan memasukan nilai lima dan satu untuk semua indikatornya ke dalam model regresi skor.

3. Menghitung beda nilai minimum dan maksimum dari skor yang mungkin untuk setiap konstruk.

4. Transformasikan nilai skor pada langkah 1, untuk memperoleh skor dengan nilai minimum 1 dan maksimum $5: 1+$ (nilai skor nilai skor minimum (langkah 2) / nilai beda (langkah 3) x 4.

5. Berdasarkan skor pada langkah 4 hitung distribusi kumulatif kurang dari, rata-rata dan simpangan bakunya.

6. Kategorisasi rata-rata tanggapan unit analisis dikelompokkan sebagai berikut:

$\begin{array}{lll}{[0-1)} & : & \text { Sangat rendah/tidak pernah/sangat tidak sesuai/sangat tidak mampu } \\ {[1-2)} & : & \text { Rendah/pernah/tidak sesuai/tidak mampu } \\ {[2-3)} & : & \text { Sedang/kadang-kadang/kurang sesuai/kurang mampu } \\ {[3-4)} & : & \text { Tinggi/sering/sesuai/mampu } \\ {[4-5)} & : & \text { Sangat tinggi/selalu/sangat sesuai/sangat mampu } \\ {[5]} & : & \text { Sempurna }\end{array}$




\section{Etika Pengguna}

Variabel etika penguna diukur dengan tiga dimensi, yaitu responsibility, accountability dan liability.Dimensi responsibility diukur melalui 2 (dua) indikator.Dimensi accountability diukur melalui 2 (dua)

Tabel 4.2

Deskriptif Statistilk Variabel Etika Pengguma

\begin{tabular}{|c|c|c|c|c|c|c|c|c|c|c|}
\hline \multirow[b]{2}{*}{ Dimensi } & \multicolumn{4}{|c|}{ Ukuran Statistik } & \multicolumn{6}{|c|}{ Frekuensi Relatif } \\
\hline & Min & Max & Rata-rata & SD & {$[0-1)$} & {$[1-2)$} & {$[2-3)$} & {$[3-4)$} & {$[4-5)$} & 5 \\
\hline \begin{tabular}{l|l|} 
Responsibi \\
liby
\end{tabular} & 2,8 & 5,0 & 4,4 & 0,5 & 0,0 & 0,0 & 1,7 & 13,8 & 70,7 & 13,8 \\
\hline $\begin{array}{ll}\text { Accoutab } \\
\text { lithy }\end{array}$ & 2,3 & 5,0 & 4,2 & 0,6 & 0,0 & 0,0 & 5,2 & 25,9 & 58,6 & 10,3 \\
\hline Liability & 2,3 & 5,0 & $\overline{4,2}$ & 0,6 & 0,0 & 0,0 & 5,2 & 29,3 & 58,6 & 6,9 \\
\hline
\end{tabular}

Dari tabel 4.2 menunjukkan bahwa diantara ketiga dimensi tersebut responsibility memiliki nilai rata-rata yang tertinggi, hal ini menunjukkan bahwa etika yang paling diperhatikan oleh pengguna dalam menjalankan sistem informasi akuntansi terdapat pada rasa tanggung jawab dan menjalankan tugas yang telah direncanakan sebelumnya.

Hasil perhitungan frekuensi relatif (tabel 4.2) dapat menjelaskan sebanyak 1,7 \% unit analisis menyatakan bahwa responsibility belum sepenuhnya dijalankan untuk mewujudkan etika yang baik bagi pengguna 5,2\% unit analisis yang menyatakan accountability belum secara keseluruhan digunakan untuk membentuk etika pengguna dalam menjalankan sistem informasi akuntansi. 5,2\% unit analisis menyatakan bahwa kewajiban untuk loyal dan menjaga kerahasiaan belum seluruhnya terbentuk dalam beretika di BUMN.Adapun penjelasan masing-masing dimensi adalah sebagai berikut:

\section{1) Responsibility}

Dimensi responsibility memiliki dua indikator yang merefleksikannya .Masing-masing indikator diwakili oleh satu item pernyataan.
Tabel 4.3

Rekapitulasi Skor Rata-rata Distribusi

Tanggapan BUMN pada Dimensi Responsibility

\begin{tabular}{|c|l|c|c|}
\hline No & \multicolumn{1}{|c|}{ Pernyataan } & $\begin{array}{c}\text { Skor } \\
\text { Rata- } \\
\text { rata }\end{array}$ & $\begin{array}{c}\text { Standar } \\
\text { Deviasi }\end{array}$ \\
\hline \hline 1 & $\begin{array}{l}\text { Saat menggunakan aplikasi SIA (program komputer) } \\
\text { selalu bertanggung jawab terhadap pekerjaan yang } \\
\text { dilakukan }\end{array}$ & 4,7 & 0,4 \\
\hline 2 & $\begin{array}{l}\text { Penggunaan aplikasi SIA (program komputer) selalu } \\
\text { melaksanakan berbagai macam bentuk pekerjaan yang } \\
\text { telah direncanakan sebelumnva. }\end{array}$ & 4,3 & 0,5 \\
\hline
\end{tabular}

Sumber: data olahan statistik

Pada tabel 4.3 dapat dilihat bahwa semua indikator memiliki skor rata-rata tanggapan responden masing-masing 4,7 dan 4,3 dan kategori jawaban responden pada kuesioner masuk dalam kategori antara sering dan selalu. Ini artinya bahwa karyawan BUMN yang menjadi sampel pada penelitian ini secara ratarata memiliki rasa tanggung jawab terhadap pekerjaan yang ditugaskannya.

\section{2) Accountability}

Dimensi accountability memiliki dua indikator yang merefleksikannya.Masing-masing indikator diwakili oleh satu item pernyataan.

Tabel 4.4

Rekapitulasi Skor Rata-rata Distribusi Tanggapan BUMN pada Dimensi Accountability

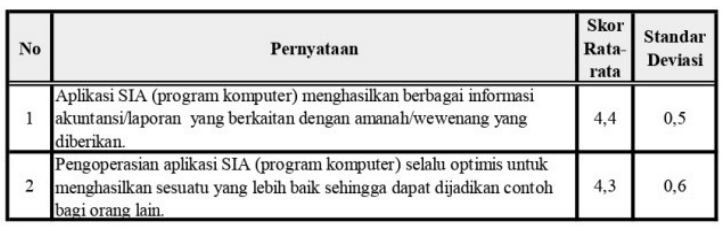

Sumber: data olahan statistik

Dari tabel 4.4 dapat dilihat bahwa skor rata-rata indikator yang pertama dari dimensi accountability adalah 4,4. Kategori jawaban responden pada kuesioner, nilai rata-rata ini masuk kedalam kategori antara sering dan selalu.Ini artinya karyawan BUMN yang menjadi sampel dalam penelitian ini dalam penggunaan 
sistem informasi akuntansi seringkali menerima tanggung jawab atas segala yang ditugaskan karena tanggung jawab merupakan amanah yang harus dijalankan. Untuk indikator yang kedua skor rata-rata jawaban responden adalah 4,3 dan masuk kedalam kategori antara sering dan selalu. Ini menunjukkan bahwa karyawan BUMN yang menjadi sampel pada penelitian ini dalam penggunaan sistem informasi akuntansi seringkali optimis untuk menghasilkan sesuatu yang lebih baik sehingga dapat dijadikan contoh bagi orang lain.

\section{3) Liability}

Dimensi liability memiliki dua indikator yang merefleksikannya.Masing-masing indikator diwakili oleh satu item pernyataan

Tabel 4.5

Rekapitulasi Skor Rata-rata Distribusi Tanggapan BUMN pada Dimensi Liability

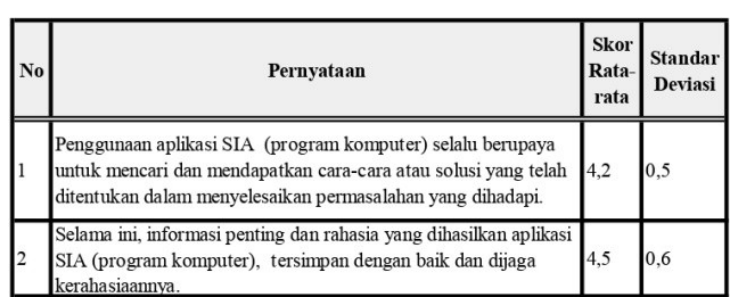

Sumber: data olahan statistik

Dari tabel 4.5 dapat dilihat bahwa skor rata-rata indikator yang pertama dari dimensi liability adalah 4,2dan masuk kedalam kategori antara sering dan selalu. Ini artinya karyawan BUMN yang menjadi sampel dalam penelitian ini dalam penggunaan sistem akuntansi perusahaan seringkali berupaya untuk mencari solusi yang terbaik jika sedang menghadapi permasalahan. Untuk indikator yang kedua skor rata-rata jawaban responden adalah 4,5dan masuk kedalam kategori antara sering dan selalu. Ini menunjukkan bahwa karyawan BUMN yang menjadi sampel pada penelitian ini dalam penggunaan sistem informasi akuntansi yang menghasilkan informasi penting dan dijaga kerahasiaannya.

\section{Kualitas Sistem Informasi Akuntansi}

Variabel kualitas sistem informasi akuntansi dioperasionalisasikan dengan menggunakan 3 (tiga dimensi), yaitu integration, flexibility dan reliability. Masing-masing dimensi dari kualitas sistem informasi akuntansi diukur melalui dua indikator.Indikator-indikator secara keseluruhan dioperasionalisasikan menjadi enam item pernyataan

Tabel 4.6

Deskriptif Statistik Variabel Kualitas Sistem Informasi Akuntansi

\begin{tabular}{|c|c|c|c|c|c|c|c|c|c|c|}
\hline \multirow{2}{*}{ Dimensi } & \multicolumn{3}{|c|}{ Ukuran Statistik } & \multicolumn{7}{|c|}{ Frekuensi Relatif } \\
\cline { 2 - 12 } & Min & Max & $\begin{array}{c}\text { Rata- } \\
\text { rata }\end{array}$ & SD & {$[0-1)$} & {$[1-2)$} & {$[2-3)$} & {$[3-4)$} & {$[4-5)$} & 5 \\
\hline Integration & 1,0 & 5,0 & 3,4 & 0,7 & 0,0 & 1,7 & 20,7 & 65,5 & 10,3 & 1,7 \\
\hline Flexibility & 1,4 & 4,6 & 3,3 & 0,6 & 0,0 & 3,4 & 22,4 & 63,8 & 10,3 & 0,0 \\
\hline Reliability & 1,7 & 4,9 & 3,4 & 0,6 & 0,0 & 3,4 & 17,2 & 67,2 & 12,1 & 0,0 \\
\hline
\end{tabular}

Sumber: data olahan statistik

Dimensi integration berkategori tinggi artinya unit analisis menganggap sistem informasi akuntansi yang digunakan telah menghubungkan antar komponen dan sistem pengolahan transaksi.Dimensi flexibility berkategori tinggi (berkualitas).Artinya selama ini sistem informasi akuntansi yang digunakan pada unit analisis mampu menyesuaikan kebutuhan pengguna dan mampu beradaptasi dengan perubahan lingkungan.

Dimensi reliability juga berkategori tinggi.Artinya sistem informasi akuntansi untuk menghasilkan laporan keuangan yang digunakan pada unit analisis selama ini dapat diandalkan dan bebas dari kesalahan. Diantara tiga dimensi tersebut, integration dan reliability memiliki 
nilai yang paling besar yang menunjukkan bahwa sistem informasi akuntansi di BUMN mayoritas telah terhubung satu sama lain dan handal. Berdasarkan hasil perhitungan frekuensi analisis (tabel 4.6) menunjukkan aplikasi sistem informasi akuntansi yang digunakan kurang mengintegrasikan antar komponen dan sistem pengolahan transaksi yaitu sebanyak 1,7\%, kurang fleksibel sebesar 3,4\% dan kurang handal sebesar 3,4\%.

\section{1) Integration}

Berikut secara rinci tanggapan responden BUMN atas pernyataan-pernyataan tentang integration.

Tabel 4.7

Rekapitulasi Skor Rata-Rata Indikator Untuk Dimensi Integration

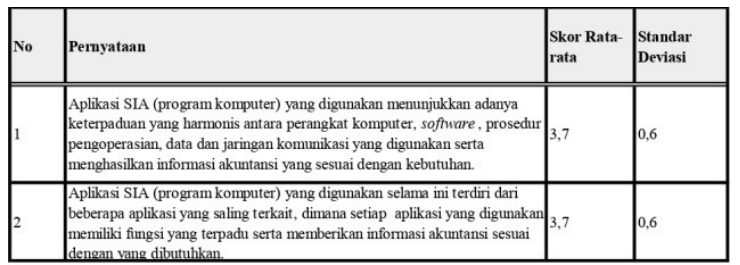

Sumber: data olahan statistik

Dari tabel 4.7 dapat dilihat bahwa rata-rata skor jawaban responden untuk indikator yang pertama dan kedua adalah 3,7. Jika dilihat dari katagori/skala jawaban responden pada kuesioner maka nilai rata-rata ini berada dalam kategori antara cukup dan sering. Ini artinya BUMN yang menjadi sampel pada penelitian ini dalam penggunaan sistem informasi akuntansi, terintegrasi baik antar komponen maupun sistem pengolahan transaksi.

\section{2) Flexibility}

Berikut secara rinci tanggapan responden BUMN atas pernyataan-pernyataan tentang flexibility. Tabel 4.8

\section{Rekapitulasi Skor Rata-Rata Indikator} Untuk Dimensi Flexibility

\begin{tabular}{|l|l|l|l|}
\hline No & Pernyataan & $\begin{array}{l}\text { Skor Rata- } \\
\text { rata }\end{array}$ & $\begin{array}{l}\text { Standar } \\
\text { Deviasi }\end{array}$ \\
\hline \hline 1 & $\begin{array}{l}\text { Aplikasi SIA (program komputer) yang } \\
\text { digunakan mampu menyesuaikan dengan } \\
\text { kebutuhan untuk menyelesaikan pekerjaan. }\end{array}$ & 3,8 & 0,5 \\
\hline 2 & $\begin{array}{l}\text { Aplikasi SIA (program komputer) yang } \\
\text { digunakan mampu menyediakan fasilitas dalam } \\
\text { menghadapi berbagai kemungkinan perubahan } \\
\text { faktor lingkungan dan dapat beradaptasi } \\
\text { secara potensial untuk perubahan sistem } \\
\text { informasi selanjutnya. }\end{array}$ & 3,5 & 0,5 \\
\hline
\end{tabular}

Sumber: data olahan statistik

Dari tabel 4.8 dapat diartikan bahwa BUMN yang menjadi sampel pada penelitian ini di dalam penggunaan sistem informasi akuntansi kadang-kadang mampu menyesuaikan dengan kebutuhan pengguna. Untuk indikator yang kedua dapat diartikan bahwa BUMN yang menjadi sampel pada penelitian ini dalam penggunaan sistem informasi akuntansi perusahaan terkadang mampu beradaptasi dengan perubahan lingkungan.

\section{3) Reliability}

Dimensi reliabilitydioperasionalisasikan dengan menggunakan 2 (dua) indikator. Masing-masing indikator diwakili oleh satu item pernyataanBerikut secara rinci tanggapan responden BUMN atas pernyataan-pernyataan tentang reliability.

\section{Tabel 4.9}

Rekapitulasi Skor Rata-Rata Indikator Untuk Dimensi Reliability

\begin{tabular}{|l|l|l|l}
\hline No & Pernyataan & $\begin{array}{l}\text { Skor Rata- } \\
\text { rata }\end{array}$ & $\begin{array}{l}\text { Standar } \\
\text { Deviasi }\end{array}$ \\
\hline \hline 1 & $\begin{array}{l}\text { Aplikasi SIA (program komputer) yang digunakan handal } \\
\text { (beroperasi secara stabil, tidak mudah error dan minim gangguan). }\end{array}$ & 3,5 & 0,6 \\
\hline 2 & $\begin{array}{l}\text { Aplikasi SIA (program komputer) yang digunakan selalu } \\
\text { menghasilkan laporan yang akurat dengan tingkat kesalahan yang } \\
\text { minimal (bebas dari kesalahan). }\end{array}$ & 3,9 & 0,5 \\
\hline
\end{tabular}

Sumber: data olahan statistik

Dari tabel 4.9 dapat dilihat bahwa skor rata-rata jawaban responden untuk indikator 
yang pertama adalah 3,5,berada dalam kategori antara kadang-kadang dan sering. Ini artinya BUMN yang menjadi sampel pada penelitian ini di dalam penggunaan sistem informasi akuntansi kadang-kadang handal artinya beroperasi secara stabil, tidak mudah error dan minim gangguan. Untuk indikator yang kedua, skor rata-rata tangapan responden 3,9 dan juga berada dalam kategori antara kadang-kadang dan sering. Ini artinya BUMN yang menjadi sampel pada penelitian ini dalam penggunaan sistem informasi akuntansi perusahaan kadang-kadang bebas dari kesalahan.

Pembahasan Determinasi Etika Pengguna terhadap Keberhasilan Sistem Informasi

\section{Akuntansi}

Berdasarkan analisis statistik deskriptif dapat dijelaskan bahwa nilai skor rata-rata jawaban BUMN yang menjadi sampel penelitian atas pengaruh etika pengguna terhadap kualitas sistem informasi akuntansi, belum berada pada kondisi sempurna dan masih bernilai 4,0 dengan kategori tinggi. Kemudian $1,7 \%$ dari BUMN yang menjadi sampel penelitian menjawab pada kisaran 1-2 yang berarti bahwa masih terdapat sistem informasi akuntansi pada BUMN tersebut, yang belum mengadopsi etika penggunanya yang terdiri dari responsibility, accountability dan liability.

Berdasarkan dari jawaban responden atas etika pengguna di BUMN, dilihat dari responsibility menunjukkan skor rata-rata sebesar 4,4 masuk dalam kategori sangat tinggi. Ini dapat diartikan bahwa dalam penggunaan sistem informasi akuntansi, pengguna selalu bertanggung jawab terhadap pekerjaan yang ditugaskan sampai pekerjaan tersebut dapat 70 diselesaikan sesuai dengan yang direncanakan sebelumnya.

Apabila dilihat dari accountability dan liability menunjukkan skor rata-rata sebesar 4,2 masuk dalam kategori sangat tinggi. Ini dapat diartikan bahwa dalam penggunaan sistem informasi akuntansi, pengguna selalu melaksanakan tugasnya sesuai dengan amanah/wewenang yang diberikan didukung dengan sikap optimis bahwa pekerjaan dapat diselesaikan dengan baik.

Hasil pengujian hipotesis pada penelitian ini menunjukkan bahwa penerapan sistem informasi akuntansi belum sepenuhnya mengadopsi etika yang dimiliki pengguna dalam menggunakan sistem informasi akuntansi. Hasil penelitian ini kemudian ditindaklanjuti dengan menghubungi beberapa responden pada unit analisis untuk mengetahui lebih detail alasan penyebab penggunaan sistem informasi akuntansi belum sepenuhnya mengadopsi etika pengguna atau dapat diartikan perubahan etika pengguna tidak berdampak pada perubahan kualitas sistem informasi akuntansi yang ada di BUMN. Dari hasil interview dengan praktisi di BUMN, dapat dijelaskan sebagai berikut :

1. Dalam hal ini etika bisa di-counter (digantikan) oleh kebijakan dan prosedur yang optimal dan sosialisasi sistem informasi akuntansi yang efektif sehingga dapat mengurangi kesalahan dalam entry data yang berpengaruh terhadap kualitas sistem informasi akuntansi.

2. Namun bagi manajer, kepala bagian atau staff yang baru harus dapat menyelesaikan pekerjaan limpahan dari karyawan sebelumnya. 
3. Terkadang aplikasi sistem informasi akuntansi mengalami error dan tindak lanjut untuk perbaikan tidak cepat sedangkan penyusunan laporan keuangan harus terus dilakukan, sehingga pengguna merasa nyaman untuk melanjutkan dengan cara manual karena tuntutan bahwa laporan keuangan harus diselesaikan dengan cepat.

4. Dengan adanya sistem informasi akuntansi yang digunakan dapat membentuk etika pengguna selaku yang mengoperasikan sistem informasi menjadi lebih baik dan bertanggung jawab dalam menyelesaikan pekerjaan.

Penjelasan tersebut diperoleh berdasarkan survey yang dilakukan kepada PT. Rajawali Nusantara Indonesia, PT Pelabuhan Indonesia II dan PT Inti.Hasil penelitian pada BUMN yang menjadi sampel dalam penelitian ini, tidak memenuhi teori dan penelitian sebelumnya. Seperti teori yang dinyatakan oleh Piccoli (2008:450) yang menyatakan etika berpengaruh terhadap sistem informasi, artinya ketika sistem informasi diterapkan, etika menjadi penuntun bagi perilaku pengguna sesuai dengan aturan yang diterapkan.

Laudon \& Laudon

(2014:152) mengemukakan bahwa seseorang harus memahami bagaimana beretika yang benar yang diperlukan dalam penggunaan sistem informasi. Lebih lanjut O'Brien\& Marakas (2011:20) menegaskan bahwa sebagai manajer, pengusaha professional dan karyawan harus memiliki tanggung jawab etis dalam penggunaan sistem informasi. Masih menurut O'Brien \& Marakas (2011:528) bahwa etika tidak dapat terlepas dari penggunaan sistem informasi, dimana dalam penggunaannya dalam bisnis, memiliki dampak besar pada masyarakat dan dengan demikian dapat menimbulkan masalah etika di bidang kejahatan, privacy, individualitas, pekerjaan, kesehatan dan kondisi kerja. Dengan demikian dapat disimpulkan bahwa hasil penelitian tidak memberikan bukti adanya pengaruh etika pengguna terhadap kualitas sistem informasi akuntansi.

Etika berkaitan dengan fungsi utama dari SIA yaitu pencatatan, pelaporan, dan pengendalian, dengan fokus pada data dan penggunaan SIA yang diperlukan sebagai pengendalian. Untuk meningkatkan kualitas sistem informasi akuntansi yang ada di BUMN, maka etika penggunanya juga harus ditingkatkan. Etika yang diharapkan adalah perilaku yang penuh tanggung jawab dan menyadari kewajibannya sebagai karyawan sehingga akan membentuk kepribadian yang baik. Oleh karena itu, di BUMN pada saat perekrutan karyawan wajib mengikuti test kepribadian.Indikator yang harus dipertimbangkan dalam meningkatkan kualitas sistem informasi akuntansi di BUMN adalah etika pengguna berupa responsibility, accountability dan liability.

\section{SIMPULAN DAN SARAN}

Simpulan

Berdasarkan fenomena, rumusan masalah, hipotesis dan hasil penelitian maka diperoleh simpulan sebagai berikut:

Etika pengguna berpengaruh terhadap keberhasilan sistem informasi akuntansi. Belum berkualitasnya sistem informasi akuntansi disebabkan responsibility, accountability dan 
liability belum sepenuhnya diakomodir di dalam penggunaan.

\section{Saran}

Berdasarkan hasil penelitian, pembahasan dan simpulan, maka saran yang dapat diajukan adalah sebagai berikut :

Etika pengguna berpengaruh terhadap kualitas sistem informasi akuntansi sehingga untuk meningkatkan kualitas sistem informasi akuntansi, beberapa hal yang perlu diperhatikan pada etika pengguna dengan fokus kepada tindakan manajemen puncak sebagai pihak yang mampu mengarahkan kebiasaan dan perilaku anggota organisasi dalam menjalankan sistem informasi akuntansi, yaitu :

a) Manajemen puncak memotivasi karyawan untuk menerapkan budaya etis, tanggung jawab, disiplin kerja, loyal dan patuh serta memberikan yang terbaik bagi organisasi dengan diterapkannya reward dan punishment. Bila organisasi melihat manajemen puncak berperilaku tidak etis maka karyawanpun akan berperilaku tidak etis pula.

b) Sebelum dilakukan perpindahan karyawan (mutasi) sebaiknya dilakukan kaderisasi dan transfer knowledge, sehingga karyawan yang baru memiliki kesepahaman yang sama agar sistem informasi akuntansi dapat tetap berjalan dengan baik dan sebagai bentuk tanggung jawab dalam menyelesaikan pekerjaan.

\section{DAFTAR PUSTAKA}

\section{Sumber Buku :}

Alter, Steven. 2002. Information Systems Foundation of E-Business. Fourth Edition. New Jersey : Pearson Education International.

Azhar Susanto. 2013. Sistem Informasi Akuntansi, Struktur-Pengendalian-Resiko Pengembangan. Bandung : Lingga Jaya.

Bagranoff, Nancy A., Simkin, Mark G. \&Norman, Carolyn S. 2010. Accounting Information System.USA :John Wiley \& Sons.

Ballantine, J, Levy M, Martin A, Munro I \& Powell P. 2000. An Ethical Perspective on Information Systems Evaluation.International Journal of Agile Management Systems 2/3. Pp 233-241.

Baltzan, Paige. 2014. Business Driven Information Systems. $4^{\text {th }}$ Edition.USA :McGraw-Hill.

Bodnar, George H\&Hopwood, William S. 2014. Accounting Information System.New Jersey :Prentice Hall.

Bollen, Kenneth A. 1989. Structural Equation with Latent Variable.John Willey \& Sons.

Chen, Charlie C, Liu, Julie Yu Chih, Chen, Houn Gee. 2011. Discriminative Effect of User Influence and User Responsibility on Information System Development Processes and Project Management. Information and Software Technology. Pp. 149-158.

Dellaportas, Steven, Gibson, Kathy, Alagiah, Ratnam, Hutchinson, Marion, Leung, Philomena \&Homrigh, David Van. 2005. Ethics, Governance \&Accountability :A Professional Perspective.Australia : John Wiley \& Sons.

DeLone, W. H \& McLean, E. R. 1992. Information System Success : The Quest of The Dependent Variable. Information Systems Research.Vol. 3. Pp. 60-95. 
DeLone, W. H \& McLean, E. R. 2003. The DeLone and McLean Model of Information System Succes : A Ten Years Update. Journal of Management Information System.19(4). Pp. 3-30.

Dessler, Gary. 2013. Human Resources Management. Twelfth Edition.USA : Prentice Hall.

Dunn, Cheryl L; Cherrington, J.Owen; Hollander, Anita S. 2005.Enterprise Information Systems: A Pattern Based Approach. Third Edition. New York :McGraw-Hill International Edition.

Gorla, Narasimhaiah, Somers, Toni M \& Wong, Betty. 2010. Organizational Impact of System Quality, Information Quality, and Service Quality. Journal of Strategic Information Systems. 2010. Pp 207-228.

Gupta, Hitesh. 2011. Management Information Systems. An Insight. New Delhi : International Book House PVT. LTD.New Delhi.

Griffin, Ricky W. 2011. Management Principles and Practices.Tenth Edition. South Western : Cengage Learning.

Hair, Joseph F.Jr, Hult, G. Tomas M, Ringle, Christian M\&Sarstedt, Marko. 2014.A Primer on partial Least Squares Structural Equation Modeling (PLS-SEM).USA : Sage Publications Asia-Pacific Pte.

Hall, James A. 2011.Accounting Information System. $7^{\text {th }}$ Edition. USA : South-Western Publishing Co.

Hartman, Laura P. \& Desjardins, Joe. 2008. Business Ethics : Decision-Making for Personal Integrity and Social Responsibility. Singapore :McGraw-Hill Companies.

Heidmann, Marcus. 2008. The Role of Management Accounting Systems in Strategic Sensemaking.Germany : Respect Copyright Encourage Creativity.

Horan, Thomas A \&Abhichandani, Tarun. 2006. Evaluating User Satisfaction in an EGovernment Initiative :Resulte of Structural
Equation Modeling and Focus Group Discussions. Journal of Information Technology Management. Pp. 187-198.

Jawadekar, Waman S. 2009. Management Information Systems. Text \& Cases. $4^{\text {th }}$. New Delhi : Tata McGraw Hill Education Private Limition.

Laudon, Kenneth C \& Laudon, Jane P. 2014. Management Information Systems Managing The Digital Firm. Thirteenth Edition.America :Pearson Prentice Hall.

Marcus, Aaron. 2009. Integrated Information Systems and Information Design.A Proffesional Field for Information Designers.Information Design Journal. July 2009. pp. 4-21. Amsterdam, Netherlands: Benjamin Publishing.

Mc. Leod, Raymond \& Schell, George P. 2007. Management Information System. Tenth Edition. Upper Saddle River New Jersey 07458 : Pearson / Prentice Hall.

McShane \&Glinow, Von. 2010. Organizational Behaviour.Fifth Edition.Singapore :McGrawHill International Edition.

Myers, Michael D \& Venable, John R. 2014.A Set of Ethical Principles for Design Science Research in Information Systems.Information \& Management. 51. Pp. 801-809.

O’Brien „James A.\&Marakas, George M. 2011.Management Information Systems. Tenth Edition. New York: McGrawHill Irwin.

Olumoye, Mosud Y. 2013. Ethics and Social Impact of Information Systems in Our Society : Analysis and Recommendation. International Journal of Science and Research. Pp. 154-158.

Piccoli, Gabriele. 2008. Information Systems for Managers. Text and Cases. USA: John Wiley \& Sons Inc. United States of America.

Robbins, Stephen \& Judge, Timothy A. 2014. Essensial of Organizational Behaviour.Twelfth Edition. USA :Pearson Education. 
Rocheleau, Bruce. 2006. Public Management Information System. 2006. All rights Reserved.

Sacer, Ivana Mamic, Zager, Katarina\&Tusek Boris. 2006. Accounting Information System's Qualityas TheGroundfor Quality Business Reporting. IADIS International Conferencee-Commerce.

Schwalbe, Kathy. 2006. Introduction to Project Management. Course Technology Thomson Learning.Inc.USA :Cengage Learning, Inc. Boston, Massachussetts.

Stair, Ralph M \& Reynolds, George W. 2012.Fundamentals of Information Systems, Sixth Edition. USA :Cengage Learning.

Stair, Ralph M \&Reynolds, George W. 2010.Principles of Information Systems, Course Technology.$^{\text {th }} \quad$ Editions. NewYork:Mc-Graw-Hill

Thompson, R. L \&\& Baril,CatsW. 2003. Information Technology \& Management.New York: McGraw-Hill.,

Weber, Ron. 1999. Information System Control and Audit. USA : Prentice-Hall International.

Wixom, B. H. \& Todd, P.A. 2005. A Theoretical Integration of User Satisfaction and Technology Acceptance.Information Systems Research. 16.(1). Pp. 85-102.

\section{Sumber Internet:}

Budi Firman. 2013. Bagian TI BuatSistemInformasiTerintegrasi. Melalui http://www.bumn.go.id/ptpn7/berita/48/Bagi an.TI.Buat.Sistem.Informasi.Terintegrasi. 10 April 2013.

M. Kuncoro W. 2014. Penerapan Teori John P Kotter pada Kesuksesan Implementasi TI. PT. KAI. Melalui :

http://www.ciocommunity.org/newsdetail/Penerapan-Teori-John-P-Kotter-padaKesuksesan-Implementasi-TI--PT-KAI/104.12 Desember 2014.

Mustafa Abubakar. 2010. Menteri BUMN BingungSistemBaru Garuda MalahBikinKacau.Melaluihttp://finance.deti k.com/read/2010/11/24/155406/1501460/4/m $\&$ enteri-bumn-bingung-sistem-baru-garudamalah-bikin-kacau. 24 Nopember 2010.

Uchok Sky Khadafi, 2012. Perusahaan BUMN

Masih Takut Transparansi Laporan

Keuangan.Melalui

http://www.tempo.co/read/newstempobisnis,

16 Juli 2012 